\title{
MOTIVATION OF ALTRUISTIC SPERM DONORS PARTICIPATING IN ASSISTED REPRODUCTION IN RUSSIAN FEDERATION
}

\author{
E.E. Symaniuk ${ }^{\text {a }}$ I.G. Polyakova ${ }^{\text {a }}$, A.G. Andal ${ }^{\mathrm{a}}$ \\ ${ }^{a}$ Ural Federal University, 19, Mira Str., Yekaterinburg, 620002, Russian Federation
}

This article explores the motivations behind Russian men's altruistic sperm donation using Alderfer's Existence-Relatedness-Growth (ERG) model. Among the sample of 86 men, altruistic motivation is mostly driven by existence and relatedness. Correlations tests indicated two patterns: 1) men driven by existence needs are more willing to maintain contact with the future child and less prone to self-promotion; 2) men driven by relatedness needs demonstrate the opposite characteristics. These results contribute to further research of reproductive donor motivations in Russia.

Keywords: assisted reproduction technologies; reproductive donation; sperm donation; sperm donors' motivation; Alderfer's ERG theory.

\section{Introduction}

This work aims to advance the discussions on reproductive donor motivations in Russia. Research on reproductive donor motivation in Russia is increasingly becoming relevant as a public health concern. In the last decade, the share of childless marriages in this country has ranged from 8 to $17.8 \%$, exceeding the critical level of $15 \%$ in some regions. This figure is expected to reach $20 \%$ in the next decade [1]. In many cases, couples remain childless because of the poor quality of sperm or genetic incompatibility [2]. These limitations, however, can be overcome with the help of assisted reproductive technologies (ARTs). As such, ARTs have received considerable critical attention, especially in connection to the subject of donation.

The current discussion seems to concentrate, among other things, on sperm donation. For a long time in Russia there has been only commercial sperm donation with rare exceptions of intrafamilial sperm donation. Although in the recent years there has been an increase in the use of altruistic sperm donation (ASD), still little is known about sperm donors' motivations. Most studies in this area limit themselves to comparing the reasons to donate [3-5]. Likewise, the body of literature on this subject includes relatively few Russian studies. So far, there is only study on sperm donation in CIS countries that investigated potential donors' attitudes to the procedure of sperm donation [6]. This study surveyed 120 men of reproductive age living in Almaty and eligible to donate sperm. Even though this study was not aimed at detailed analysis of respondents' moti- 
vations, it identified three main motivations (in the descending order): desire to help, desire to earn money and commitment to civic duty.

Over the past decade, most research in sperm donation has emphasized that sperm donors may be guided by extrinsic (commercial) or intrinsic motives. The latter, which is the focus of this study, ranges from altruism to desire to please oneself $[7,8]$. Altruistic motives may include the desire to fulfill one's perceived moral duty, for instance, to give one's parents grandchildren or to become a better version of oneself, such as being 'a responsible individual, a good husband or father, a person of high morals, a loving son' [9]. In contrast, some studies consider self-interest as the primary motivation behind sperm donation. For instance, Bossema et al [7] identified egoism stemming from narcissism and desire to procreate as the main motive of sperm donation. Many donors also seek to continue their family line, pass on their genes or confirm their fertility status [10-12]. Sperm donation can be also seen as a proof of virility or, as Mohr puts it, 'embodied masculinity', associated with the 'boost-experience' as a part of experiencing 'sexual excitement and gratification through masturbation at the sperm bank' [9].

It is quite difficult to set a clear distinction between altruistic and commercial motives of sperm donation. Even though some kind of material reward is welcome [4], the absence of remuneration usually has little to no influence on the decision to donate, especially among younger people [8]. Money is of secondary importance [5] and is sometimes regarded not so much as a reward for donation [13] but as a way of fulfilling other moral obligations the donor has in relation to his family [9].

Among the indirect factors affecting donors' motivations, the most significant is anonymity. Some donors request anonymity to avoid tensions with their wife/partner and children [9]. In countries where sperm donation anonymity is prohibited, sperm donation may happen in informal settings, outside of state regulation [7]. Many donors believe that open-identity sperm donation means 'being morally responsible' towards their future offspring [9]. Open-identity donation also varies for the type of donor-recipient relationship. For example, brother sperm donation is considered a suitable intra-family reproductive arrangement while other forms of donation (brother-sister or father-daughter) may be considered as incest. Donors and their partners may feel differently about donation and in certain situations donors prefer not to ask for their partner's approval, while others seek their partners' consent [7, 12].

Together, these studies show that the motivations behind sperm donation are diverse and complex, although we have not found any studies that systematized and ascribed these motives within any contemporary motivation theories. Moreover, the socio-psychological factors and concurrent factors for assisted conception or prevalence of certain motivations still remain a largely underexplored question, which this study seeks to address.

This study aims to bridge the above-mentioned research gaps by identifying and systematizing motivations of sperm donors within the framework of Clayton P. Alderfer's Existence-Relatedness-Growth model. The ERG theory proposes to 
group Maslow's hierarchy of needs into the three-level hierarchy of needs: existence needs, relatedness needs and growth needs [14]. In comparison with Maslow's model, Alderfer categorized physiological and safety needs as existence; social needs (love and belonging) as relatedness; and esteem and selfactualization as growth. It should be stressed that Alderfer's model is not hierarchical in the sense that it does not imply a direct movement from lower-level to higher-level needs. Since our study focuses on altruistic motivations, it uses Alderfer's ERG model to explain what internal perspectives lead humans to certain behaviors [15]. This approach has been validated by many studies and widely discussed in theoretical and empirical works, often in combination with other approaches to motivation [16]. Moreover, since most of the prior research using the ERG model focuses on job satisfaction and job value [17], our work makes a meaningful contribution to this field by applying this framework to explain the motivations for altruistic reproductive donation.

The main focus of our research is altruistic sperm donation. We are going to describe and classify the key motivations of altruistic sperm donors according to Alderfer's ERG model and identify the main factors that determine the dominance of certain motivations or types of motivations. It should be noted at this point that while most Russian studies tend to distinguish between the terms 'motivations' and 'needs', in our research we will use these terms interchangeably.

The objectives of the study are as follows: first, we analyze on-line questionnaires completed by potential sperm donors and classify the key motivations of ASD within the framework of Alderfer's ERG model. Second, we conduct a preliminary (exploratory) analysis of correlations between the motivations and socio-psychological factors with other concurrent factors. Third, we run a factor analysis to simplify the large number of variables and then establish whether any correlation exists between donors' motivations and socio-psychological factors and concurrent factors through a logistic regression.

Theoretical hypotheses:

1. Motivations of altruistic sperm donors can be classified according to the categories of Alderfer's ERG theory.

2. Donors may be driven by different motivations corresponding to different types of needs.

Empirical hypotheses:

1. The following motivations of altruistic sperm donors correlate with different socio-psychological factors: age, sexual orientation, education, having naturallyconceived children, income, attitude to alcohol, attitude to sport, health status and self-assessed success in life.

2. There are also other aspects in which altruistic donors differ (concurrent factors), including the following: the recipient woman's relationship status; having naturally-conceived children; childhood photos; photos of relatives; children and medical tests results posted on the web-site; desire for further contacts with the resulting child; considering the possibility of marrying the recipient woman; willingness to travel to another city and cover the travel and living costs; willingness to cover the costs of ART; willingness to support the future mother and 
child; attitude to assisted reproduction; willingness to register as the child's legal father; requesting guarantees that the donor will be under no obligations towards the resulting child; prior donation experience; willingness to discuss being a donor with one's friends and family members; and considering it necessary that the donor and recipient women should have mutual attraction.

\section{Materials and Methods}

A random sample of 130 donors with profile pictures was selected from 5,800 men registered as online sperm donors on the website Rebyonku Byt' (https://rebenku.biz). Rebyonku Byt' is the largest open on-line resource in Russia dedicated to connecting sperm donors and recipients (women or couples). From the sample of 130 sperm donors, 86 respondents were selected based on informed consent tailored with opportunities to empower research subjects by considering them as stakeholders who can provide their views, opinions and motivations in relation to their own practices or other sperm donors. As such, which are reflected on the following sampling criteria:

1) a donor is willing to donate sperm for assisted reproduction;

2) a donor is willing to donate sperm on an altruistic basis;

3) a donor is willing to use the services of fertility clinics.

Socio-demographic characteristics and some information on motivation were obtained from the online questionnaires the potential donors completed on this web-site. To collect more data on ASD, we asked these donors to answer additional multiple choice and open-ended questions (see Appendices 1 and 2). Descriptive analysis was used to discuss the socio-demographic characteristics of the donors. The quantitative data were analyzed using PCA (principal component analysis) to summarize all possible variabilities of several components of motivation. PCA was used because the number of observed variables in this study is rather large and thus needed to be collapsed into a smaller number of interpretable underlying factors (principal components) to account for most of the variance of the observed variables. The results of PCA were further analyzed by using multivariate analysis in order to find relationships between these variables.

\section{Results}

\section{Characteristics of sperm donors}

The average age of respondents was $37.4(\mathrm{SD}=6.9)$. The majority of sperm donors (76) were from Russia while others were from neighboring countries such as Ukraine, Belarus and Kazakhstan. A half of Russian respondents (39) live in Moscow while others live in large regional cities such as St. Petersburg. Figure 1 shows the basic demographic characteristics of the respondents. In terms of socio-economic status, more than a half of sperm donors $(67.4 \%)$ come from the middle-income group; almost $30 \%$ belong to the high-income group and only $3.5 \%$ have a low-income socio-economic status. There are also more married sperm donors (62\%) than single ones (38\%). As for education, the ma- 
jority of our respondents have higher education (88.4\%), and only $12 \%$ have not completed higher education.

Socio-Economic Status

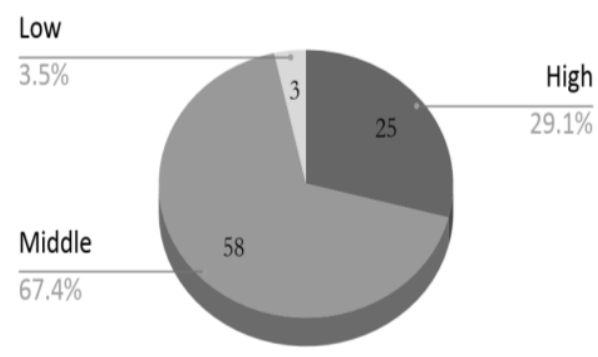

Marital Status

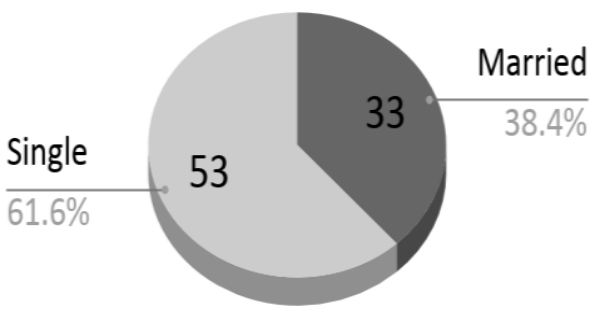

\section{Education}

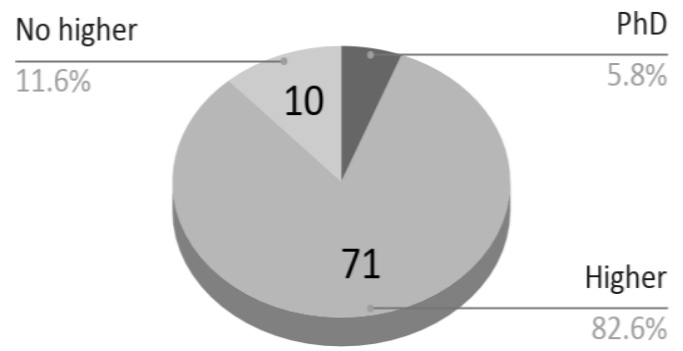

Fig. 1. Distribution of respondents by education, income and marital status

Figure 2 shows that almost all respondents are employed, many of them hold managerial positions (35) or work in engineering and IT (11).

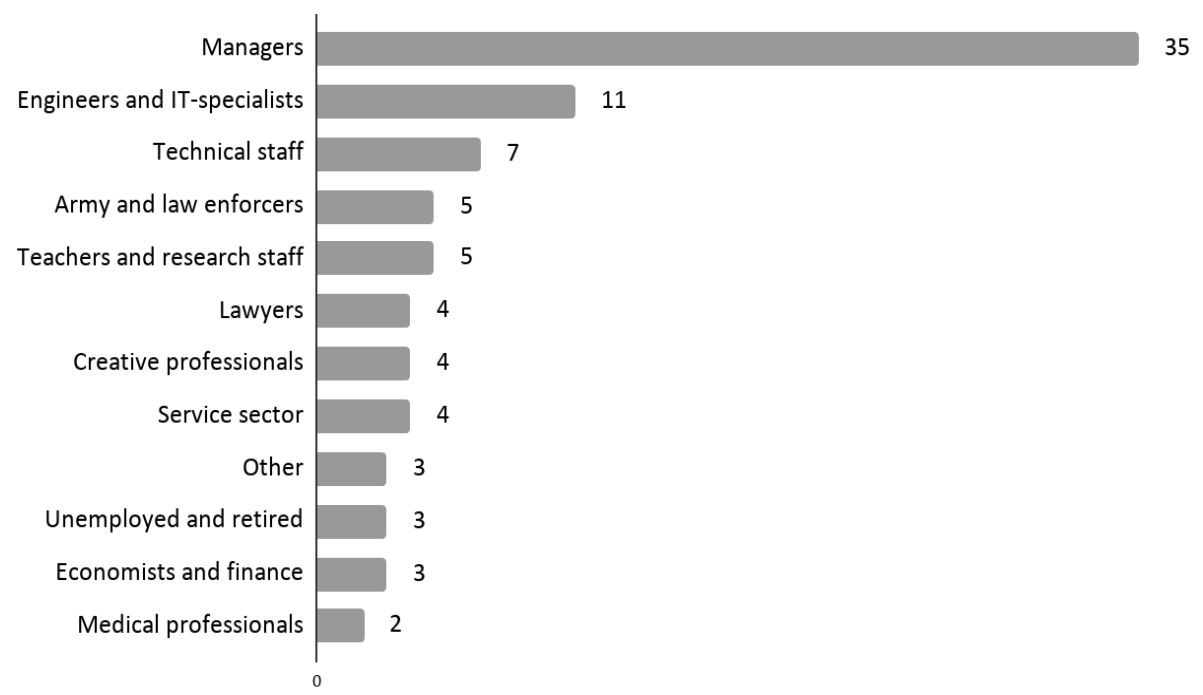

Fig. 2. Distribution of respondents by occupation 
Most of the respondents consider themselves to be healthy (self-rated health status on a 10-point grading scale) (See Figure 3). None of the respondents smoke, less than a half (33) do not drink alcohol, while others drink alcohol only on rare occasions. Almost all of the respondents claim that they engage in sports: more than a half regularly do sports (47) and others (39) do so from time to time.

40

20

10

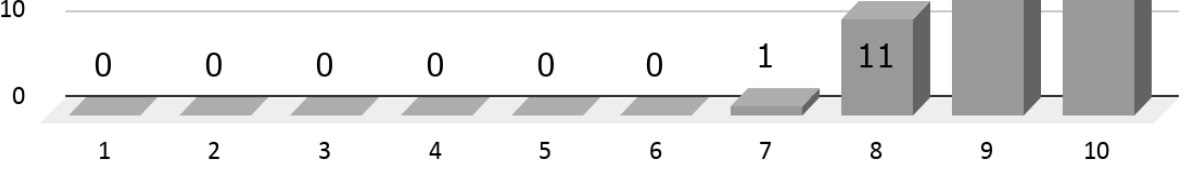

self-rating

Fig. 3. Distribution of respondents by self-assessed health status

Experience and Attitude on Sperm Donation

Table 1

\begin{tabular}{|l|c|c|}
\hline \multicolumn{1}{|c|}{ Experience and Attitude } & $n$ & $\%$ \\
\hline Sperm donation experience & 38 & 44.2 \\
\hline have prior experience of sperm donation & 48 & 55.8 \\
\hline no experience & & \\
\hline Child conception & 44 & 51.2 \\
\hline have naturally-conceived children & & \\
\hline conceived children through donation & 25 & 29.0 \\
\hline neither & 17 & 19.8 \\
\hline Attitude to further contacts between the donor and child & 1 & \\
\hline obligatory & 33 & 37.5 \\
\hline desirable & 19 & 21.6 \\
\hline possible & 9 & 10.2 \\
\hline impossible & 26 & 29.5 \\
\hline depends on the mother's decision or unimportant & & \\
\hline Attitude to the use of ARTs & 28 & 32.9 \\
\hline positive & 12 & 14.1 \\
\hline neutral & 7 & 8.2 \\
\hline know little about ARTs & 10 & 11.8 \\
\hline consider artificial insemination as the only option & 11 & 12.9 \\
\hline ART is harmful to the mother's health but it is up to the woman to decide & 11 & 12.9 \\
\hline it is the end result that matters regardless of the method & 3 & 3.5 \\
\hline $\begin{array}{l}\text { have mixed feelings because of such issues as signing agreements and } \\
\text { disclosing personal information }\end{array}$ & 3 & 3.5 \\
\hline believe that ART should be used only in cases of medical necessity & & \\
\hline
\end{tabular}


The end of table 1

\begin{tabular}{|l|c|c|}
\hline \multicolumn{1}{|c|}{ Experience and Attitude } & $n$ & $\%$ \\
\hline Willingness to register as the resulting child's legal father & & \\
\hline Willing & 22 & 25.6 \\
\hline Unwilling & 64 & 74.4 \\
\hline Willingness to marry the recipient woman & & \\
\hline Willing & 12 & 14.0 \\
\hline unimportant & 15 & 17.4 \\
\hline Unwilling & 59 & 68.6 \\
\hline $\begin{array}{l}\text { Willingness to spend resources (time, money, effort) for the donation } \\
\text { process }\end{array}$ & & \\
\hline Willing to go to another city and to cover the travel and living expenses & 36 & 41.8 \\
\hline $\begin{array}{l}\text { Cannot travel to another city but is ready to cover the travel and living } \\
\text { expenses for the recipient woman in his own city }\end{array}$ & 1 & 1.2 \\
\hline $\begin{array}{l}\text { Willing to travel to another city provided that the recipient woman co- } \\
\text { vers all the expenses. }\end{array}$ & 3 & 3.5 \\
\hline $\begin{array}{l}\text { willing to cover the cost of ART } \\
\text { Unwilling to spend any resources }\end{array}$ & 7 & 8.1 \\
\hline
\end{tabular}

All respondents consider ART acceptable, although there are certain differences in their attitudes (Table 1).

\section{Categorized responses according to the ERG Model}

We investigated respondents' motivations by analyzing their answers to the questions 'What influenced your decision to become a sperm donor?' and 'Why do you need to be a sperm donor?' together with the additional information provided by respondents. As seen in Table 2, we used content-analysis to categorize the responses according to the ERG model. Since the responses are highly related and overlapping, we applied fuzzy classification, which means that one response may belong to several categories (See Appendices 3-6 for examples). The majority (76 out of 86) of respondents demonstrate only one type of need. Most responses on motivation for sperm donation fall under the category of existence needs.

Table 2

Frequency and description of responses categorized within the ERG Model

\begin{tabular}{|c|c|c|}
\hline \multicolumn{3}{|l|}{ Existence $\mathrm{n}=48(55 \%)$} \\
\hline $\begin{array}{l}\text { A1 - desire to pass down } \\
\text { one's genes }\end{array}$ & $\begin{array}{l}\text { A2 - desire to pass down } \\
\text { one's genes to as many } \\
\text { offspring as possible }\end{array}$ & $\begin{array}{l}\text { A3 - desire for children and } \\
\text { heirs }\end{array}$ \\
\hline $\begin{array}{l}\text { A10 - absence of genetic, } \\
\text { mental, oncological or } \\
\text { other serious diseases }\end{array}$ & $\begin{array}{l}\text { A21-description of one's } \\
\text { genotype }\end{array}$ & \\
\hline $\begin{array}{l}\text { A11-professional } \\
\text { achievements of } \\
\text { ancestors }\end{array}$ & $\begin{array}{l}\text { A22-improvement } \\
\text { of the nation's gene pool }\end{array}$ & \\
\hline $\begin{array}{l}\text { A12 - successful socializa- } \\
\text { tion of members of one's } \\
\text { family line }\end{array}$ & $\begin{array}{l}\text { A23 - description of the } \\
\text { donor's children and their } \\
\text { positive characteristics }\end{array}$ & \\
\hline
\end{tabular}


The end of table 2

\begin{tabular}{|c|c|c|}
\hline \multicolumn{3}{|l|}{ Relatedness $\mathrm{n}=36(41 \%)$} \\
\hline $\begin{array}{l}\text { B1 - desire to maintain } \\
\text { contact with one's children, } \\
\text { participate in their upbring- } \\
\text { ing }\end{array}$ & B2 - feeling of loneliness & $\begin{array}{l}\text { B3-desire to help people. } \\
\text { B10-desire to make some- } \\
\text { one happy. } \\
\text { B11-desire to make the } \\
\text { world better }\end{array}$ \\
\hline \multicolumn{3}{|l|}{ Growth $\mathrm{n}=12(14 \%)$} \\
\hline $\begin{array}{l}\mathrm{C} 1 \text { - interest in pursuing a } \\
\text { new activity }\end{array}$ & $\begin{array}{l}\mathrm{C} 2-\text { search for the aim and } \\
\text { meaning in life }\end{array}$ & \\
\hline \multicolumn{3}{|l|}{ Narcissism $n=23(26 \%)$} \\
\hline $\begin{array}{l}\text { D1 - emphasis on one's } \\
\text { physical characteristics and } \\
\text { display of the most attrac- } \\
\text { tive personal qualities }\end{array}$ & $\begin{array}{l}\text { D2 - detailed description of } \\
\text { one's achievements: } \\
\text { D10 - in education; } \\
\text { D11 - in career; } \\
\text { D12 - in hobbies }\end{array}$ & $\begin{array}{l}\text { D3 - desire to assert oneself } \\
\text { at the expense of a woman }\end{array}$ \\
\hline
\end{tabular}

Table 3

Significant coefficients of correlations between the needs and factors

\begin{tabular}{|l|c|c|c|c|}
\hline \multicolumn{1}{|c|}{ Motivation Predictors } & Existence & Relatedness & Growth & Narcissism \\
\hline $\begin{array}{l}\text { Childhood photos, photos of relatives, } \\
\text { children and medical tests results in the } \\
\text { respondent's account }\end{array}$ & $-0.25^{*}$ & $0.27^{*}$ & & $0.36^{* *}$ \\
\hline Having naturally-conceived children & $-0.31^{* *}$ & & $0.23^{*}$ & \\
\hline Having donor-conceived children & & $0.23^{*}$ & & \\
\hline Attitude to sport & & & & $0.25^{*}$ \\
\hline $\begin{array}{l}\text { Possibility of further contacts with the } \\
\text { child }\end{array}$ & & $-0.23^{*}$ & & \\
\hline Willing to cover the costs of ART & & & & $0.30^{* *}$ \\
\hline Ready to support the mother and child & $0.30^{* *}$ & $-0.31^{* *}$ & & \\
\hline $\begin{array}{l}\text { Willing to register as the child's legal } \\
\text { father }\end{array}$ & $0.40^{* *}$ & $--0.37^{* *}$ & & \\
\hline Previous donation experience & $-0.44^{* *}$ & $0.44^{* *}$ & & \\
\hline $\begin{array}{l}\text { Ready to discuss being a donor with one's } \\
\text { friends and family members }\end{array}$ & $0.32^{* *}$ & $-0.38^{* *}$ & & \\
\hline Self-assessed success in life & & & & $0.22^{*}$ \\
\hline
\end{tabular}

$*-\mathrm{p} \leq 0.05 ; * *-\mathrm{p} \leq 0.01$.

We used multivariate analysis for a preliminary (exploratory) investigation of the connections between sperm donors' motives and socio-psychological and concurrent factors. Since the majority of the variables are dichotomous, we used the dichotomous and point biserial correlation coefficients as the main measures. Based on the obtained data, we built models to predict the presence of a need of a certain type by using a set of specific factors. Principal Component Analysis with Varimax Rotation was conducted to assess the observed variables. Modelling was done according to the logistic regression algorithm with step-bystep exclusion of predictors. Table 3 shows statistically significant coefficients of the correlations between certain types of need and the supposed motivation predictors (See Appendix 3 for correlation coefficients). 


\section{Existence needs: donation as a moral obligation}

Existence needs have a significant relationship with the variables related to commitment, personal/moral responsibility and openness to sperm donation, which means that personal beliefs and principles underlie the decision to donate (for example, 'the only value in life is children, the rest is dust in the wind' or 'my aim is to improve the nation's gene pool'). In other words, in this case, the sense of moral obligation is crucial to the donor's decision-making [9]. The negative correlation between existence needs and having naturally-conceived children and previous donation experience show that donation is taken seriously. This implies that those donors who are motivated by existence needs exhibit a sense of responsibility, prudence and cautiousness in their decisions. A sense of responsibility is demonstrated in such responses as 'when my child reaches the age of 18 , I will buy him a good flat' and 'I want to invest my time and money in the future - in children'.

\section{Relatedness needs: donation as an act of kindness}

Relatedness is found to have significant relationships with a sense of moral obligation and child-related variables. But unlike the existence needs, relatedness needs are negatively correlated with moral obligations. For instance, readiness to support the mother and child has an inverse relationship with relatedness needs. Moreover, relatedness needs are positively correlated with having donorconceived children and previous donation experience, which means that relatedness speaks more about being helpful than having long-term commitments (for example, 'I help women and couples to become happier in this world' or 'I will help a woman to become a mother'). These statements show that while the donor is willing to help, donation stems from the desire to contribute to other's goals. Donors with the prevalent relatedness need consider donation more as a onetime act of kindness rather than a matter of principle. In other words, being positively correlated with previous donation experience and having donor-conceived children, donation is treated as a 'no-strings-attached' act rather than as a longterm responsibility (for example, 'I want to feel needed, to give warmth and love to people who are close to me' or 'I make the world a little brighter and warmer').

\section{Growth needs: donation as an experience and self-discovery}

Since there is only one variable significantly correlated to growth needs, it is difficult to draw a conclusive interpretation regarding this type of motivation. Interestingly though, it is positively correlated to having naturally-conceived children. As it has previously been noted by Alderfe [14] himself, people with higher self-esteem are more open to new experiences. Taking into consideration the fact that growth needs are associated with self-esteem, our results are in agreement with those of the previous studies. If we look at the statements in our respondents' profiles, a self-discovery attitude is observed: 'open for anything new'; 'one more sphere of activity'; 'desire to realize my potential'; 'I would like to try something new' and 'I need a real aim in life. I thought that it could be a child'. This positive correlation, therefore, suggests that growth-driven donation 
is perceived by donors as a self-discovery activity and a novel experience after having naturally-conceived children.

\section{Narcissism and egoism: prestige of donation}

It is not surprising that narcissism has a positive correlation with variables related to hierarchy and self-image such as sports and self-assessed success in life as well as having photos in one's profile. Sperm donation motivated by narcissism shows that prestige may be a driving force for donors (for example, 'I am physically strong, tall, have blonde curly hair, green eyes, I am the Slavic or Nordic type'; 'good even teeth, without any flaws or fillings' and 'I created a mobile phone retail and wholesale network from scratch').

Models were built to predict the presence of certain types of motivation in the motivation structure of altruistic sperm donors. First, we conducted a factor analysis in order to reduce the number of predictors in the model and eliminate the negative effects of multicollinearity. The method of parallel analysis was used to identify the optimal number of factors.

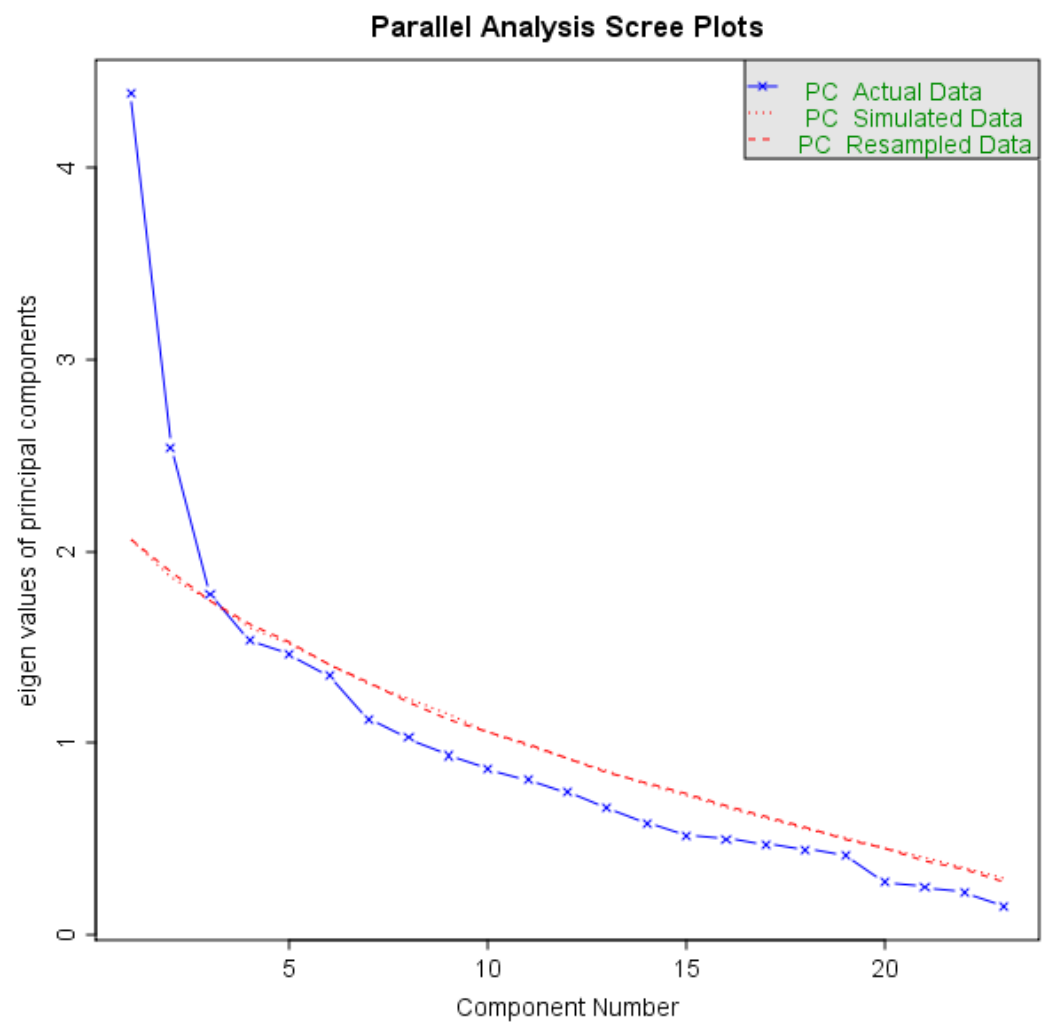

Fig. 4. Results of parallel analysis

As Figure 4 shows, three factors are sufficient to describe and represent the motivation variables. When this criterion is applied in the resulting factor 
matrix, there are no loadings on several important variables. We, therefore, decided to choose six factors, since factors 4-6 were very close to the line of the random factor matrix's own values. In Table 4, six variables describe and represent the motivation for donation, namely 'age' (F1), 'responsibility' (F2), 'social status' (F3), 'self-promotion' (F4), 'desire to start a family' (F5) and 'willingness to cover the costs of ART' (F6). Many of the results in this factor matrix reflect the findings discussed in the correlation table (Table 3).

Table 4

Variables from factor analysis results with Varimax rotation of 6 principal components

\begin{tabular}{|l|c|c|c|c|c|c|}
\hline \multicolumn{1}{|c|}{ Variable } & F1 & F2 & F3 & F4 & F5 & F6 \\
\hline Age & 0.73 & 0.1 & -0.18 & 0.09 & 0.22 & 0.07 \\
\hline $\begin{array}{l}\text { Recipient woman's relationship status } \\
\text { (single or married) }\end{array}$ & -0.57 & -0.1 & -0.4 & -0.03 & -0.25 & 0.18 \\
\hline Attitude to alcohol & 0.74 & -0.02 & 0.05 & -0.13 & -0.21 & -0.04 \\
\hline Homosexual orientation & -0.13 & 0.54 & 0.01 & -0.17 & -0.06 & 0.14 \\
\hline Having naturally-conceived children & 0 & -0.53 & 0.2 & 0.19 & 0.15 & 0.47 \\
\hline Health state & -0.4 & -0.37 & 0.15 & 0.22 & 0.02 & 0.25 \\
\hline Willing to cover the costs of ART & -0.01 & 0.38 & 0.12 & 0.31 & -0.15 & 0.52 \\
\hline Ready to support the mother and child & 0.2 & 0.65 & 0.39 & -0.02 & 0.18 & 0.1 \\
\hline $\begin{array}{l}\text { Ready to register as the child's legal } \\
\text { father }\end{array}$ & 0.29 & 0.74 & 0.05 & 0.07 & 0.26 & 0.06 \\
\hline $\begin{array}{l}\text { Willing to tell friends and family } \\
\text { members about being a donor }\end{array}$ & 0.04 & 0.75 & 0.05 & 0.18 & 0.31 & -0.01 \\
\hline Self-assessed success in life & 0.05 & 0.05 & 0.57 & 0.33 & -0.15 & 0.01 \\
\hline \begin{tabular}{l} 
Education \\
\hline Ready to marry the recipient woman
\end{tabular} & -0.01 & -0.02 & 0.74 & -0.01 & 0.1 & -0.02 \\
\hline Income & -0.14 & 0.36 & -0.47 & 0.29 & 0.39 & -0.39 \\
\hline Attitude to sport & -0.29 & 0.08 & 0.14 & 0.59 & 0.05 & 0.14 \\
\hline $\begin{array}{l}\text { Childhood photos, photos of relatives, } \\
\text { children and medical tests results in- } \\
\text { cluded in the profile }\end{array}$ & 0.04 & -0.18 & 0.11 & 0.63 & 0.03 & 0.07 \\
\hline Attitude to assisted reproduction & 0.28 & 0.18 & 0.01 & 0.41 & -0.03 & 0.23 \\
\hline Having donor-conceived children & -0.14 & -0.09 & -0.21 & 0.39 & -0.65 & 0.06 \\
\hline $\begin{array}{l}\text { Desire to maintain contact with the } \\
\text { resulting child }\end{array}$ & 0.07 & 0.52 & 0.12 & 0.15 & 0.58 & 0.05 \\
\hline $\begin{array}{l}\text { The donor needs guarantees that he } \\
\text { will be under no obligations towards } \\
\text { the resulting child }\end{array}$ & -0.14 & 0 & 0.06 & -0.2 & -0.57 & -0.26 \\
\hline Previous donation experience & -0.3 & -0.46 & -0.05 & 0.39 & -0.49 & -0.01 \\
\hline $\begin{array}{l}\text { Mutual attraction between the donor } \\
\text { and recipient woman }\end{array}$ & -0.2 & 0.11 & -0.07 & -0.03 & 0.66 & -0.09 \\
\hline $\begin{array}{l}\text { Willing to travel to another city and } \\
\text { cover the travel and living costs }\end{array}$ & -0.09 & 0.1 & -0.03 & -0.11 & 0.09 & 0.84 \\
\hline
\end{tabular}

In narrowing down the variables to the most significant model that explains altruistic donation, the highlight of this study is revealed: among the components of ERG, the existence and relatedness models have the largest number of variables to account for. This is not surprising given that at the early stage of this research, 
we found that most respondents fell under the categories of existence or relatedness needs (See Table 2). Taking into consideration the factor matrix and the multivariate analysis (Tables 4 and 5), we see that the existence and relatedness models have most significant relationships, albeit in opposite directions, with the matrix variables. Both models are significantly associated with the variables explained by responsibility (F2) and self-promotion (F4), which gives a total of eight variables in the matrix. It should be also noted that self-promotion $(\mathrm{F} 4)$ accounts for the variability of attitudes to ART, which means that altruistic motivation is driven by existence-based and relatedness-based needs rather than the desire for new experiences (growth need).

Table 5

Coefficient table for the multivariate analysis

\begin{tabular}{|l|c|c|c|c|}
\hline \multicolumn{1}{|c|}{ Model } & Coefficients & Standard error & z-score & p-value \\
\hline Existence need model & 0.35 & 0.25 & 1.37 & 0.17 \\
\hline (Intercept) & 1.17 & 0.33 & 3.52 & $0.00^{* *}$ \\
\hline Responsibility & -0.63 & 0.27 & -2.35 & $0.02^{*}$ \\
\hline Self-promotion & -0.49 & 0.26 & -1.85 & 0.06 \\
\hline Relatedness need model & -1.16 & 0.34 & -3.39 & $0.00^{* *}$ \\
\hline (Intercept) & -0.44 & 0.24 & -1.84 & 0.07 \\
\hline Responsibility & 0.56 & 0.26 & 2.11 & $0.04^{*}$ \\
\hline Desire to start a family & -0.49 & 0.26 & -1.85 & 0.06 \\
\hline Self-promotion & -0.51 & 0.38 & -1.35 & 0.18 \\
\hline Growth need model & 0.57 & 0.41 & 1.41 & 0.16 \\
\hline (Intercept) & \multicolumn{5}{|l}{} \\
\hline Responsibility & -1.30 & 0.31 & -4.25 & 0.00 \\
\hline Social status & 0.53 & 0.32 & 1.65 & 0.10 \\
\hline Narcissism and egoism model & 1.20 & 0.33 & 3.64 & $0.00^{*}$ \\
\hline (Intercept) & F1 & \multicolumn{5}{|l}{} \\
\hline F4 &
\end{tabular}

$*-\mathrm{p} \leq 0.05 ; * *-\mathrm{p} \leq 0.01$.

As shown in Figure 5, the existence and relatedness models are more accurate compared to the growth model. The relatedness model predicts the presence and absence of motivation in $69 \%$ and $82 \%$ of cases, respectively. The existence model, while less accurate, still predicts the presence and absence of motivation in $75 \%$ of cases and its absence, in $63 \%$. In contrast, the growth model exhibits an even poorer accuracy, which can be explained by the low frequency of this need. For a more accurate model, expanded sample data are needed. Finally, the narcissism and egoism model is also not suitable for drawing a classification and its results are not significantly different from random. It may be that growth needs are the least altruistic among the ERG factors. While growth needs are different from narcissism by and large, they are still closely related to each other. One theory is that narcissism is a compensation for the lack of esteem and feeling of inferiority and inadequacy [18]. This implies that among all the needs, growth needs are the most self-serving, which do not cohere with altruistic tendencies. 


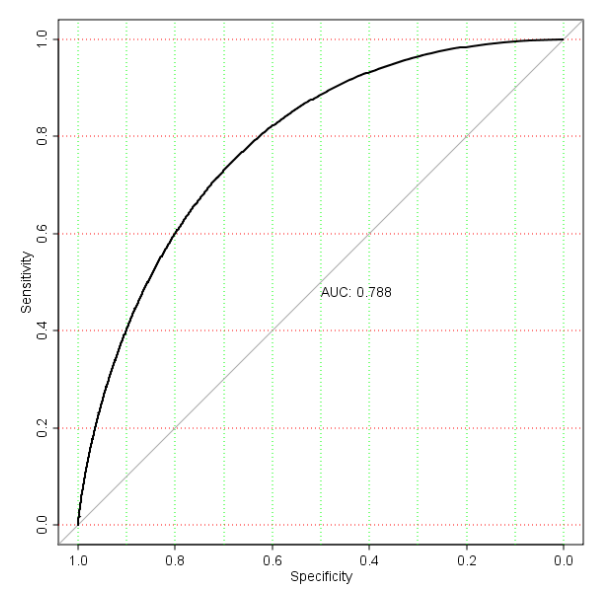

Existence need model

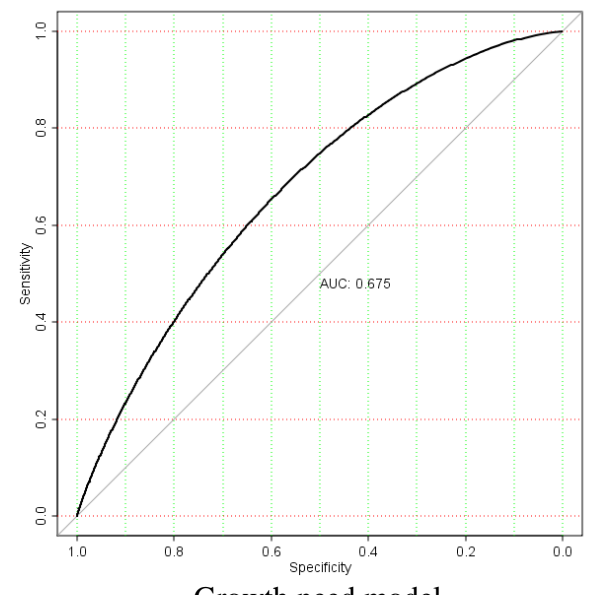

Growth need model

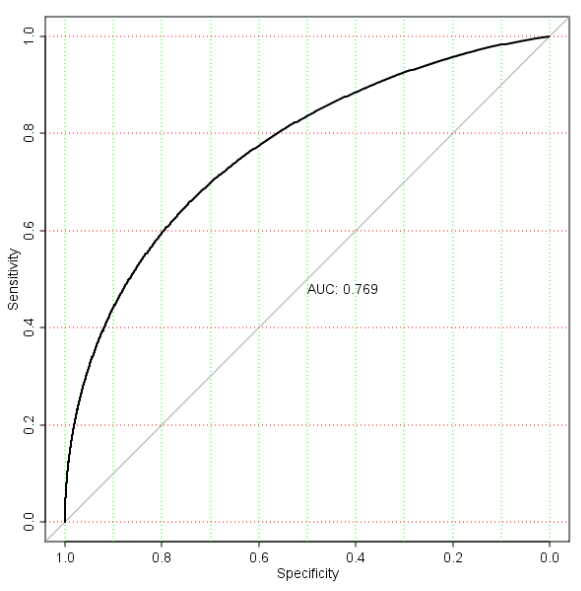

Relatedness need model

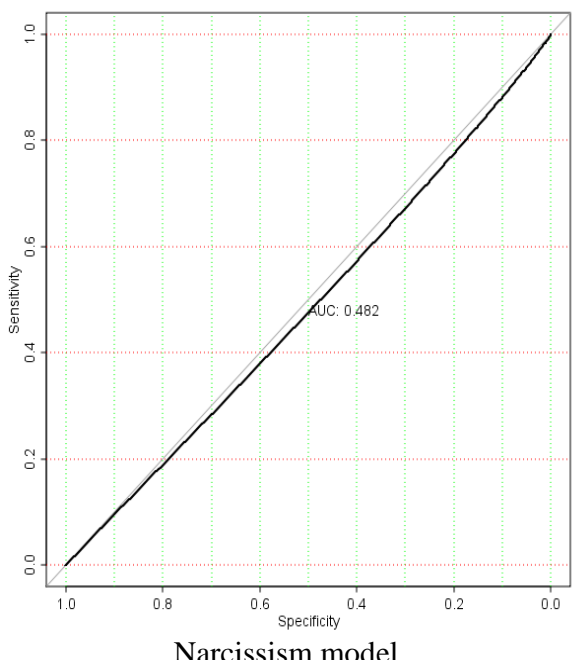

Narcissism model

Fig. 5. ROC-curve of the components of ERG Model

On the contrary, existence and relatedness needs do not go in line with narcissistic tendencies, which is why these were found significantly associated with altruistic motivation.

\section{Conclusions}

This study gives insights into the motives for donation of altruistic sperm donors. Given the initial skepticism towards this type of donation in the medical field, investigating the motives behind sperm donation can help better understand this phenomenon. Our study contributes to the existing research field in three ways: first, it explores the possibilities of applying the ERG Model 
to study altruistic donors' motivations; second, it offers insights into the differences between the existence and relatedness models in altruistic sperm donation; and, finally, it shows the significance of sperm donation in the Russian context.

We found that altruistic donation is mostly driven by the existence and relatedness needs. The altruistic donors in this study have displayed characteristics such as the 'desire to help others' and 'desire to do something good in life'. This finding is consistent with the previous research in Kazakhstan [6]. The desire to help directly correlates with the altruistic motives as described by Mohr [9] in the study of Danish sperm donors. Our findings also agree with those of Bossema et al. [7], which revealed that sperm donors may be guided by egoistic concerns stemming from narcissism, albeit found insignificant. Moreover, while both existence and relatedness models determine altruistic motivation, they differ in how they influence altruistic motivation (See Table 3 and 5). For instance, the existence need has a positive correlation with factors such as readiness to accept responsibility for the resulting child and a negative correlation with the inclination to self-promote as a donor. Interestingly, we found completely opposite tendencies for those donors who demonstrated the relatedness need, which means that these needs are not only two different types of motivations but also reveal two different systems of motivations and behavioural patterns. Nevertheless, the evidence we had at our disposal was not enough to confirm this hypothesis and further inquiry into this question is required.

The novelty of our research is determined by the lack of studies on Russian sperm donors' motivations even though assisted-reproduction technologies are now rapidly developing in this country and the demand for such technologies is growing. This is of particular interest because it is a novel idea for a married man in Russia to help another woman to conceive (relatedness), to support her during pregnancy and raise the resulting child (existence). This phenomenon requires further study, taking into account the fact that, in 2018, the population of Russia declined by 93.5 thousand people $(0.06 \%)$ [19]. Further research could include an expanded sample size for a more comprehensive understanding of this complex phenomenon and/or focus on recipients' and donors' attitudes to 'open-identity' donation, which is also quite new to Russia.

Our analysis has produced some interesting results and insights concerning donor motivations that should be further explored and verified in future studies. Our findings can be useful for the development of methods of psychological counselling for donors and recipients at the decision-making stage. For instance, identification of sperm donor type (existence, relatedness or growth) can be implemented in pre-donation counselling in order to achieve an appropriate 'match' between donors and recipients. It is highly likely that better understanding of the true motivations behind altruistic sperm donation will help facilitate contact between donors and recipients and ease decision-making for recipients. Our results can be also beneficial for ART clinics, which will be able to recruit donors more efficiently such as recruiting men from groups or associations that exhibit existence and relatedness motives, such as socio-civic or charity groups, 
rather than sport clubs (growth motive). Another opportunity is to have advertising strategy or press coverage that target existence and relatedness motives. Further research is encouraged to examine sperm donation and in particular altruistic motivations of sperm donors by using qualitative methodologies. We hope that these results will serve as a starting point for further research into reproductive donor motivations in Russia.

\section{References}

1. Adamyan, L.V., Filippova, G. \& Kalinskaya, M. (2012) Coping patterns of infertile women. Meditsinskiy vestnik. Severnogo Kavkaza-Medical News of the North Caucasus. 3(27). pp. 101-107. (In Russian).

2. Berberović, L., Redzić, A. \& Sosić, B. (2004) Impact of ABO blood groups on the fertility of different parental pairs. Bosnian Journal of Basic Medical Sciences. 4(4). pp. 19-24. DOI: $10.17305 / \mathrm{bjbms.2004.3354}$

3. Pedersen, B., Nielsen, A.F. \& Lauritsen, J.G. (1994) Psychosocial aspects of donor insemination. Sperm donors-their motivations and attitudes to artificial insemination. Acta Obstetricia et Gynecologica Scandinavica. 73(9). pp. 701-705. DOI: $10.3109 / 00016349409029407$

4. Ernst, E., Ingerslev, H.J., Schou, O. \& Stoltenberg, M. (2007) Attitudes among sperm donors in 1992 and 2002: a Danish questionnaire survey. Acta Obstetricia et Gynecologica Scandinavica. 86(3). pp. 327-233. DOI: https://doi.org/10.1080/00016340601133913

5. Freeman, T., Jadva, V., Tranfield, E. \& Golombok, S. (2016) Online sperm donation: a survey of the demographic characteristics, motivations, preferences and experiences of sperm donors on a connection website. Human Reproduction. 31(9). pp. 2082-2089. DOI: 10.1093/humrep/dew166

6. Komogortsev, A. \& Oshibaeva, A. (2015) The problem of donation of male gametes. Tsentral'no-Aziatskiy nauchno-prakticheskiy zhurnal po obshchestvennomu zdravookhraneniyu - Journal of Central Asian Health Services Research. 3. pp. 28-35. (In Russian).

7. Bossema, E.R., Janssens, P., Landwehr, F., Treucker, R., van Duinen, K., Nap, A. \& Geenen, R. (2012) A taxonomy of possible reasons for and against sperm donation. Acta Obstetrica et Gynecologica Scandinavica. 92(6). pp. 679-685. DOI: 10.1111/aogs.12059

8. Bay, B., Larsen, P.B., Kesmodel, U.S. \& Ingerslev, H.J. (2014). Danish sperm donors across three decades: motivations and attitudes. Fertility and Sterility. 101(1). pp. 252257. DOI: $10.1016 /$ j.fertnstert.2013.09.013

9. Mohr, S. (2014) Beyond motivation: on what it means to be a sperm donor in Denmark. Anthropology \& Medicine. 21(2). pp. 162-173. DOI: 10.1080/13648470.2014.914806

10. Jadva, V., Casey, P., Readings. J., Blake, L. \& Golombok, S. (2012) A longitudinal study of recipients' views and experiences of intra-family egg donation. Human Reproduction. 26(10). pp. 2777-2782. DOI: 10.1093/humrep/der252

11. Riggs, D.W. \& Russell, L. (2011) Characteristics of men willing to act as sperm donors in the context of identity-release legislation. Human Reproduction. 26(1). pp. 266-272. DOI: 10.1093/humrep/deq314

12. Van den Broeck, U., Vandermeeren, M., Vanderschueren, D., Enzlin, P., Demyttenaere, K. \& D'Hooghe, T. (2013) A systematic review of sperm donors: demographic characteristics, attitudes, motives and experiences of the process of sperm donation. Human Reproduction Update. 19. pp. 37-51. DOI: 10.1093/humupd/dms039

13. Hoeyer, K. (2013) Exchanging Human Bodily Material: Rethinking Bodies and Markets. Dordrecht: Springer. pp. 1-191. 
14. Alderfer, C. (1969) An empirical test of a new theory of human needs. Organizational Behavior and Human Performance. 4(2). pp. 142-175. DOI: 10.1016/00305073(69)90004-X

15. Caulton, J. (2012) The Development and Use of the Theory of ERG: A Literature Review. Emerging Leadership Journeys. 5(1). pp. 2-8. [Online] Available from: https://pdfs.semanticscholar.org/987d/845327fb5cf0c2977a18b6b16e90c4918744.pdf (Accessed: 20th May 2020).

16. Chang, W. \& Yuan, S. (2008) A synthesized model of Markov chain and ERG theory for behavior forecast in collaborative prototyping. Journal of Information Technology Theory and Application. 9(2). pp 45-63. [Online] Available from: http://aisel.aisnet.org/jitta/ (Accessed: 20th May 2020).

17. Arnolds, C.A. \& Boshoff, C. (2002) Compensation, esteem valence and job performance: an empirical assessment of Alderfer's ERG theory. The International Journal of Human Resource Management. 13(4). pp. 697-719. DOI: 10.1080/09585190210125868

18. Kernberg, O. (1975). Borderline conditions and pathological narcissism. New York: New York Universities Press. pp. 1-361.

19. The Federal State Statistics Service (Rosstat). (2019) Socio-Economic Situation in Russia. Report of the Federal State Statistics Service (Rosstat) of January 2019. [Online] Available from: http://www.gks.ru/wps/wcm/connect/rosstat_main/rosstat/ru/statistics/publications/ catalog/doc_1140086922125 (Accessed: 25th May 2020).

Received 20.08.2020; Revised 09.10.2020;

Revised 13.10.2020; Accepted 19.11.2020

\section{On-line questionnaire}

Appendix 1

1. Age.

2. Country, city.

3. Sexual orientation.

4. Marital status.

5. Employment (income level).

6. Attitude to smoking.

7. Attitude to alcohol.

8. Attitude to sport.

9. Self-assessed health status.

10. HIV and hepatitis status.

11. Conception method.

12. Possibility of the biological father's further contact with the child.

13. Possibility of the donor's marrying the recipient woman.

14. Payment to the partner.

15. I am looking for a recipient among: heterosexual women, single lesbian women, lesbian couples and heterosexual couples.

16. Commentary (additional information).

\section{Additional questions}

Appendix 2

1. The donor's profile featured childhood photos, photos of relatives, children and medical tests results (to create additional motivation).

2. Occupation.

3. Having naturally-conceived children.

4. Having donor-conceived children. 
5. Ready to come to the recipient woman's city of residence and cover the travel and living costs.

6. Ready to cover the costs of ART.

7. Ready to support the mother and child.

8. Attitude to assisted reproduction.

9. Ready to register as the child's legal father.

10. Guarantees needed that the donor will be under no obligations towards the resulting child.

11. Previous experience of sperm donation.

12. Self-assessed success in life.

13. Ready to tell friends and family about being a donor.

14. Mutual attraction between the donor and recipient woman.

15. What influenced your decision to become a sperm donor?

16 . Why do you need to be a sperm donor?

Appendix 3

\section{Examples of the indicators of the existence need}

\begin{tabular}{|c|c|c|}
\hline $\begin{array}{c}\text { First-order } \\
\text { subcategory }\end{array}$ & $\begin{array}{l}\text { Second-order } \\
\text { subcategory }\end{array}$ & Indicators \\
\hline \multirow{3}{*}{ A1 } & A10 & $\begin{array}{l}\text { 'my grandmother died when she was in her late nineties, and } \\
\text { until her death she'd had the blood pressure of } 120 / 80 \text { and the } \\
\text { normal blood sugar level'; 'my grandparents were long-livers'; } \\
\text { 'the first time my father went to the dentist is when he was } 45 \text { ' }\end{array}$ \\
\hline & A11 & $\begin{array}{l}\text { 'my mother is an engineer, my father is the head of the Forest- } \\
\text { ry Office; my first grandfather was a headmaster; first grand- } \\
\text { mother, a teacher; my second grandfather, a colonel in the } \\
\text { Soviet Army; 'among my ancestors there were scientists, } \\
\text { engineers, state officials, entrepreneurs, famous military } \\
\text { commanders and other distinguished people' }\end{array}$ \\
\hline & A12 & $\begin{array}{l}\text { 'some members of my family were quite distinguished - they } \\
\text { had memorial plaques dedicated to them, Wikipedia web- } \\
\text { pages, they were mentioned in textbooks'; 'there are a few } \\
\text { celebrities among my relatives: once I drew a detailed family } \\
\text { tree - surely, it can't be just for nothing?' }\end{array}$ \\
\hline \multirow{3}{*}{ A2 } & A21 & $\begin{array}{l}\text { 'genetically, I come from a North Russian dynasty. I know } \\
\text { my haplogroup. I have a strong immune system, no allergies } \\
\text { or genetic diseases in the male or female lines. Men in my } \\
\text { family go bald by the age of } 45 \text {, children have long arms and } \\
\text { legs and big eyes' }\end{array}$ \\
\hline & A22 & $\begin{array}{l}\text { 'the urge to procreate is perfectly natural - it's a basic instinct'; } \\
\text { 'genes of people who die childless will totally disappear in } \\
100 \text { years'; 'improvement of the nation's gene pool'; 'sooner or } \\
\text { later we will have to enhance the nation's gene pool' }\end{array}$ \\
\hline & A23 & $\begin{array}{l}\text { 'my daughter is very clever and pretty'; 'I have two children, boys, } \\
\text { both healthy'; 'we have one child and are expecting the second, } \\
\text { the first is so good-looking you can't take your eyes of him' }\end{array}$ \\
\hline A3 & & $\begin{array}{l}\text { 'I want to leave my mark behind through children'; 'I need an heir', } \\
\text { 'when my child reaches the age of } 18 \text {, I will buy him a good flat' }\end{array}$ \\
\hline A4 & & $\begin{array}{l}\text { 'the only value in life is children, the rest is dust in the wind'; } \\
\text { 'children are the most important thing'; 'to put it simply, chil- } \\
\text { dren are human immortality'; 'I want to invest my time and } \\
\text { money in the future - in children' }\end{array}$ \\
\hline
\end{tabular}


Examples of the indicators of the relatedness need

\begin{tabular}{|c|c|l|}
\hline $\begin{array}{c}\text { First-order } \\
\text { subcategory }\end{array}$ & $\begin{array}{c}\text { Second-order } \\
\text { subcategory }\end{array}$ & \multicolumn{1}{|c|}{ Indicators } \\
\hline B1 & $\begin{array}{l}\text { 'a child is necessary to feel happy, I want to feel needed, to } \\
\text { give warmth and love to people who are close to me'; 'I would } \\
\text { like to give something to this tiny human being that we are } \\
\text { going to bring into this world'; 'children should be born in } \\
\text { love (through IVF or in any other way - doesn't matter)'; 'just } \\
\text { in case you need an awesomely talented and loving father for } \\
\text { your child - write me' }\end{array}$ \\
\hline B2 & B10 & $\begin{array}{l}\text { 'I am single, I am afraid to die childless'; 'I have nobody to tell } \\
\text { about what I do' }\end{array}$ \\
\hline B3 & $\begin{array}{l}\text { 'It would be nice to know that somebody has become happier, } \\
\text { knowing this is valuable for me'; 'I help women and couples to } \\
\text { a mother. I want to benefit from the opportunity God gives } \\
\text { me while I still can and share this bundle of joy with you' }\end{array}$ \\
\hline & B11 & $\begin{array}{l}\text { 'I make the world a little brighter and warmer'; 'I am sure that } \\
\text { in modern society there should not be such a problem as } \\
\text { infertility, which is now faced by a high percentage of women } \\
\text { and couples, I am an altruist'; 'I help unconditionally those } \\
\text { who really need it (I donate not only sperm but also blood, I } \\
\text { help on the roads and help search for missing people...)' }\end{array}$ \\
\hline
\end{tabular}

Examples of the indicators of the growth need

Appendix 5

\begin{tabular}{|c|c|l|}
\hline $\begin{array}{c}\text { First-order } \\
\text { subcategory }\end{array}$ & $\begin{array}{c}\text { Second-order } \\
\text { subcategory }\end{array}$ & \multicolumn{1}{|c|}{ Indicators } \\
\hline C1 & $\begin{array}{l}\text { 'open for anything new'; 'one more sphere of activity'; 'desire } \\
\text { to realize my potential'; 'I want to live a second life'; 'I have } \\
\text { achieved everything, I would like to try something new' }\end{array}$ \\
\hline C2 & $\begin{array}{l}\text { 'I am not looking for sex on the side (I can easily find it if I } \\
\text { want to) but for meaning in everyday life'; 'I fill my life with } \\
\text { meaning, I understand that children are not mine it's just my } \\
\text { sperm, but still...'; 'I need a real aim in life. I thought that it } \\
\text { could be a child' }\end{array}$ \\
\hline
\end{tabular}

Examples of the indicators of egoism and narcissism

Appendix 6

\begin{tabular}{|c|c|l|}
\hline $\begin{array}{c}\text { First-order } \\
\text { subcategory }\end{array}$ & $\begin{array}{c}\text { Second-order } \\
\text { subcategory }\end{array}$ & \multicolumn{1}{c|}{ Indicators } \\
\hline D1 & $\begin{array}{l}\text { 'I am physically strong, tall, have blonde curly hair, green eyes, } \\
\text { I am the Slavic or Nordic type'; 'good even teeth, without any } \\
\text { flaws or fillings; 'I have dark hair, I am tall and good-looking' }\end{array}$ \\
\hline D2 & $\begin{array}{l}\text { 'I am responsible and caring, open and outgoing, positive and } \\
\text { interesting'; 'independent, neither lazy nor stupid, not selfish, } \\
\text { morally stable, willing to make compromises in a relationship, } \\
\text { upbeat and not prone to depression'; 'intelligent, successful, } \\
\text { sensible, hard-working' }\end{array}$ \\
\hline
\end{tabular}


The end of appendix 6

\begin{tabular}{|c|c|c|}
\hline $\begin{array}{c}\text { First-order } \\
\text { subcategory }\end{array}$ & $\begin{array}{l}\text { Second-order } \\
\text { subcategory }\end{array}$ & Indicators \\
\hline \multirow{3}{*}{ D3 } & D10 & $\begin{array}{l}\text { 'intellect. Since school, when I took part in regional olympi- } \\
\text { ads. I have a diploma with honours'; 'two higher educations in } \\
\text { economics and law'; 'technical vocational training and two } \\
\text { higher educations...I just like learning, I think this is what } \\
\text { keeps my young' }\end{array}$ \\
\hline & D11 & $\begin{array}{l}\text { 'I was a poor village boy who grew into a well-off Mos- } \\
\text { covite'; 'I created a mobile phone retail and wholesale network } \\
\text { from scratch'; 'I have been in coaching for seven years'; 'I've } \\
\text { started several businesses: a beauty salon, shop, cafe, gym, } \\
\text { and so on'; 'I worked as an investor }\end{array}$ \\
\hline & D12 & $\begin{array}{l}\text { 'I am good at photography'; 'in the future I would like to make } \\
\text { a music video - I will write the lyrics and music and perform } \\
\text { the song myself. I am going to do everything - from devising } \\
\text { the concept to directing the video' }\end{array}$ \\
\hline D4 & & $\begin{array}{l}\text { 'I am looking for a non-smoking, confident woman, with } \\
\text { natural beauty (no botox, silicone, especially huge silicone } \\
\text { lips), preferably well-off'; 'I am not a fan of fatherlessness and } \\
\text { I am not delighted at the prospect of my children living } \\
\text { somewhere without my help or supervision. However, I un- } \\
\text { derstand some women's situation and their urge to be a mother } \\
\text { and I am ready to help them as long as we like each other' }\end{array}$ \\
\hline
\end{tabular}

\section{Coefficients of correlation between the needs and factors}

Appendix 7

\begin{tabular}{|l|c|c|c|c|}
\hline \multicolumn{1}{|c|}{ Variable } & Existence & Relatedness & Growth & Narcissism \\
\hline Age & 0.06 & 0.01 & -0.08 & 0.00 \\
\hline $\begin{array}{l}\text { Recipient woman's relationship status } \\
\text { (single or has a husband/partner) }\end{array}$ & -0.15 & 0.18 & 0.03 & -0.10 \\
\hline Homosexual orientation & 0.17 & -0.16 & -0.08 & 0.03 \\
\hline $\begin{array}{l}\text { Childhood photos, photos of relatives, } \\
\text { children and medical tests results included } \\
\text { in the donor's profile }\end{array}$ & $-0.25^{*}$ & $0.27^{*}$ & -0.16 & $0.36^{* *}$ \\
\hline Education & 0.05 & 0.00 & 0.07 & 0.17 \\
\hline Having naturally-conceived children & $-0.31^{* *}$ & 0.17 & $0.23^{*}$ & 0.08 \\
\hline Having donor-conceived children & -0.20 & $0.23^{*}$ & -0.10 & 0.09 \\
\hline Income & 0.08 & -0.10 & 0.12 & 0.10 \\
\hline Attitude to alcohol & 0.05 & 0.06 & 0.05 & -0.10 \\
\hline Attitude to sport & 0.07 & -0.11 & 0.08 & $0.25^{*}$ \\
\hline Health state & -0.12 & 0.14 & 0.14 & 0.19 \\
\hline $\begin{array}{l}\text { Possibility of further contacts with the } \\
\text { child }\end{array}$ & 0.14 & $-0.23^{*}$ & -0.13 & 0.21 \\
\hline Possibility of marrying the recipient woman & -0.10 & 0.09 & -0.15 & 0.09 \\
\hline $\begin{array}{l}\text { Willing to travel to another city and cover } \\
\text { the travel and living costs }\end{array}$ & 0.10 & -0.20 & 0.09 & -0.05 \\
\hline Willing to cover the costs of ART & 0.01 & -0.08 & 0.00 & $0.30^{* *}$ \\
\hline Ready to support the mother and child & $0.30^{* *}$ & $-0.31^{* *}$ & -0.03 & 0.08 \\
\hline Attitude to assisted reproduction & -0.05 & 0.07 & -0.02 & 0.11 \\
\hline
\end{tabular}


The end of appendix 7

\begin{tabular}{|l|c|c|c|c|}
\hline \multicolumn{1}{|c|}{ Variable } & Existence & Relatedness & Growth & Narcissism \\
\hline Ready to register as the child's legal father & $0.40^{* *}$ & $-0.37^{* *}$ & -0.18 & 0.09 \\
\hline $\begin{array}{l}\text { Guarantees needed that the donor will be } \\
\text { under no obligations towards the resulting } \\
\text { child }\end{array}$ & 0.02 & 0.09 & 0.04 & -0.04 \\
\hline Previous donation experience & $-0.44^{* *}$ & $0.44^{* *}$ & 0.10 & 0.12 \\
\hline $\begin{array}{l}\text { Ready to discuss being a donor with friends } \\
\text { and family members }\end{array}$ & $0.32^{* *}$ & $-0.38^{* *}$ & 0.03 & 0.12 \\
\hline Self-assessed success in life & 0.15 & -0.09 & 0.02 & $0.22^{*}$ \\
\hline $\begin{array}{l}\text { Mutual attraction between the donor and } \\
\text { recipient woman }\end{array}$ & 0.18 & -0.20 & 0.00 & 0.05 \\
\hline
\end{tabular}

* - correlation is significant at the 0.05 level; ${ }^{* *}$ - correlation is significant at the 0.01 level.

Elvira E. Symanyuk - Head of the Department of General and Social Psychology Ural Federal University. Professor, D. Sc. (Psychol.).

E-mail: e.e.symaniuk@urfu.ru

Irina G. Polyakova - Researcher, Ural Center for Advanced Studies, Ural Federal University.

E-mail: irinapolykova@yandex.ru

Aireen Grace Andal - Researcher and PhD Student, Ural Federal University.

E-mail: aandal@urfu.ru / aireengracetandal@gmail.com

For citation: Symaniuk, E.E., Polyakova, I.G., Andal, A.G. Motivation of Altruistic Sperm Donors Participating in Assisted Reproduction in Russian Federation. Sibirskiy Psikhologicheskiy Zhurnal - Siberian journal of psychology. 2020; 78: 34-54. doi: $10.17223 / 17267080 / 78 / 3$.

\section{Мотивация добровольных доноров спермы, принимающих участие в программах искусственного оплодотворения в Российской Федерации}

\section{Э.Э. Сыманюка, И.Г. Полякова ${ }^{a}$, А.Г. Андала}

${ }^{a}$ Уральский федеральныій университет им. первого Президента России Б.Н. Ельиина», 620002, Россия, Екатеринбург, ул. Мира, 19

\section{Резюме}

Цель данного исследования - выявление и систематизация мотивов донорства в рамках модели потребностей Альдерфера. Были использованы результаты опроса 86 респондентов-мужчин со средним возрастом 37,4 года ( $\mathrm{SD}=6,9$ лет), отобранных на основе анкет, заполненных ими на сайте https://rebenku.biz. Ключевым критерием отбора послужила их готовность к добровольному донорству спермы с использованием ВРТ.

Ответы респондентов были распределены по трем классам согласно модели Альдерфера (потребности в существовании, в связи и в росте). Использовались принципы нечеткой классификации: один и тот же ответ мог указывать на наличие более чем одного типа потребности. Наиболее выраженными оказались потребности существования и связи, потребность в росте была достаточно редкой.

Анализ взаимосвязи преобладающего типа потребности с рядом социальнопсихологических и других факторов позволяет нам утверждать наличие по крайней мере двух мотивационно-поведенческих комплексов. Мужчины, чьей основной потребностью является потребность в существовании, в большей степени готовы принимать 
участие в жизни будущего ребенка и в меньшей степени склонны к «саморекламе», в то время как мужчины, чьей основной потребностью является потребность в связи, обладают противоположными качествами.

Ключевые слова: вспомогательные репродуктивные технологии (ВРТ); репродуктивное донорство; донорство спермы; мотивация доноров спермы; ERG теория Альдерфера.

$$
\text { Поступила в редакцию 20.08.2020 2.; повторно 09.10.2020г.; }
$$
повторно 13.10.2020 г.; принята 19.11.2020 г.

Сыманюк Эльвира Эвальдовна - доктор психологических наук, профессор, заведующая кафедрой психологии Уральского федерального университета им. первого Президента России Б.Н. Ельцина.

E-mail: e.e.symaniuk@urfu.ru

Полякова Ирина Геннадьевна - научный сотрудник Уральского межрегионального института общественных наук Уральского федерального университета им. первого Президента России Б.Н. Ельцина.

E-mail: irinapolykova@yandex.ru

Андал Айрин Грейс - аспирант Уральского федерального университета им. первого Президента России Б.Н. Ельцина.

E-mail: aandal@urfu.ru / aireengracetandal@gmail.com 